\title{
TDG regulates cell cycle progression in human neural
}

\section{progenitors [version 1; peer review: 2 approved with}

\section{reservations]}

\author{
Igal Germanguz¹, Jenny C. Park², Jessica Cinkornpumin¹, Aryeh Solomon", \\ Minori Ohashi1-3, William E. Lowry (i)1-3
}

${ }^{1}$ Eli and Edythe Broad Center for Regenerative Medicine, University of California, Los Angeles, Los Angeles, CA, 90095, USA
2Department of Molecular Cell and Developmental Biology, University of California, Los Angeles, Los Angeles, CA, 90095, USA
3Molecular Biology Institute, University of California, Los Angeles, Los Angeles, CA, 90095, USA

V1 First published: 26 Apr 2018, 7:497

https://doi.org/10.12688/f1000research.13801.1

Latest published: $26 \mathrm{Apr} 2018, \mathbf{7 : 4 9 7}$

https://doi.org/10.12688/f1000research.13801.1

\begin{abstract}
Background: As cells divide, they must both replicate their DNA and generate a new set of histone proteins. The newly synthesized daughter strands and histones are unmodified, and must therefore be covalently modified to allow for transmission of important epigenetic marks to daughter cells. Human pluripotent stem cells (hPSCs) display a unique cell cycle profile, and control of the cell cycle is known to be critical for their proper differentiation and survival. A major unresolved question is how hPSCs regulate their DNA methylation status through the cell cycle, namely how passive and active demethylation work to maintain a stable genome. Thymine-DNA glycosylase (TDG), an embryonic essential gene, has been recently implicated as a major enzyme involved in demethylation.
\end{abstract}

Methods: We use human pluripotent stem cells and their derivatives to investigate the role of TDG in differentiation and proliferation. To perform loss of function of TDG, RNA Interference was used. To study the cell cyle, we engineered human pluripotent stem cells to express the FUCCI tool which marks cells at various stages of the cell cycle with distinct patterns of fluorescent proteins. We also used cell cycle profiling by FACS, and DNA methylation analysis to probe a connection between DNA demethylation and cell cycle.

Results: Here we present data showing that TDG regulates cell cycle dynamics in human neural progenitors (NPCs) derived from hPSCs, leading to changes in cell cycle related gene expression and neural differentiation capacity. These data show that loss of TDG function can block differentiation by driving proliferation of neural progenitors. We also identify specific cell cycle related genes whose expression changes upon loss of TDG expression.

Conclusions: These observations suggest that TDG and active demethylation play an important role in hPSC cell cycle regulation and

\section{Open Peer Review}

\begin{tabular}{ccc} 
Approval Status & $? ?$ & \\
& 1 & 2 \\
\hdashline & $?$ & $?$ \\
version 1 & view & view
\end{tabular}

1. Alexey Ruzov (D), University of Nottingham, Nottingham, UK

Abdulkadir Abakir ID, University of Nottingham, Nottingham, UK

2. Rahul Prasad ID, Fox Chase Cancer Center, Philadelphia, USA

Timothy Yen, Fox Chase Cancer Center, Philadelphia, USA

Alfonso Bellacosa iD, Fox Chase Cancer

Center, Philadelphia, USA

Any reports and responses or comments on the article can be found at the end of the article. 
differentiation.

\section{Keywords}

TDG, DNA methylation, human neural progenitors

Corresponding author: William E. Lowry (blowry@ucla.edu)

Author roles: Germanguz I: Conceptualization, Formal Analysis, Investigation, Methodology, Writing - Review \& Editing; Park JC: Investigation; Cinkornpumin J: Investigation; Solomon A: Investigation; Ohashi M: Investigation; Lowry WE: Conceptualization, Formal Analysis, Funding Acquisition, Investigation, Project Administration, Resources, Supervision, Writing - Original Draft Preparation, Writing - Review \& Editing

Competing interests: No competing interests were disclosed.

Grant information: This work was supported by NIH (P01GM9913), Allen Distinguished Investigator award from the Allen Frontiers Group to WEL, A CIRM Basic Biology Award (RT-2), and pilot support from the BSCRC at UCLA (Rose Hills Scholar Award). The funders had no role in study design, data collection and analysis, decision to publish, or preparation of the manuscript.

Copyright: @ 2018 Germanguz I et al. This is an open access article distributed under the terms of the Creative Commons Attribution License, which permits unrestricted use, distribution, and reproduction in any medium, provided the original work is properly cited. Data associated with the article are available under the terms of the Creative Commons Zero "No rights reserved" data waiver (CC0 1.0 Public domain dedication).

How to cite this article: Germanguz I, Park JC, Cinkornpumin J et al. TDG regulates cell cycle progression in human neural progenitors [version 1; peer review: 2 approved with reservations] F1000Research 2018, 7:497

https://doi.org/10.12688/f1000research.13801.1

First published: 26 Apr 2018, 7:497 https://doi.org/10.12688/f1000research.13801.1 


\section{Introduction}

Coordinated changes to the epigenome are known to be essential for lineage specification and maintenance of cellular identity. DNA methylation and histone modifications critically contribute to epigenetic maintenance of chromatin structures and gene expression programs. DNA methylation can silence genomic regions, directly or indirectly, and play an important role during mammalian development. Loss of methylation in specific locations is associated with differentiation towards specific germ layers as binding of several transcription factors is strongly associated with specific loss of DNA methylation in one germ layer, and in many cases a reciprocal gain in the other layers. However, the mechanism for the lineage related site specific demethylation is not currently known. A major open question is whether this is the result of an active or passive demethylation after repeated cell division ${ }^{1,2}$. Promoters with low $\mathrm{CpG}$ content are more likely to be methylated in human embryonic stem cells (ESCs). Conversely, these same promoters are demethylated and actively expressed during differentiation in a celltype-specific manner ${ }^{3-5}$. Demethylation can occur by a passive mechanism in which the normal function of DNMT1/UHRF1 is insufficient or disrupted ${ }^{2,6}$. Alternatively, evidence for the existence of an active mechanism in which the cytosine modifications are enzymatically removed is accumulating ${ }^{1,7-9}$. Which of these mechanisms is responsible for demethylation changes in early human development is not currently known.

We and others have shown that standard differentiation protocols of hPSC leads to derivation of an embryonic-like cell rather than a mature, postnatal-like cell ${ }^{10}$. We previously identified a group of embryonic related genes which are differentially expressed in the PSC progeny of all three lineages and in tissues of the early gestation period rather than in their respective cell types of later developmental stages. Among these genes, we identified Thymine DNA Glycosylase (TDG), a gene that was recently implicated in active DNA demethylation ${ }^{10}$. Unlike other glycosylases, $T D G$ is essential for embryonic viability as $T D G$ null embryos die around E11.5-12.5 of internal hemorrhage ${ }^{8}$. The lethal phenotype was also associated with aberrant promoter methylation and imbalanced histone modifications. In addition there is evidence that levels of this enzyme are linked to progression through specific cell cycle stages. Here we provide evidence that that $T D G$ regulates cell cycle related gene expression in human neural progenitors (NPCs) derived from hPSCs and controls their capacity for differentiation towards neurons and glia. These observations suggest that TDG and active demethylation play an important role in hPSC cell cycle regulation and differentiation.

\section{Results \\ Expression of DNA demethylases through neural development}

We originally identified $T D G$ in a screen for genes that were consistently differently expressed between human pluripotent derivatives and their in vivo counterparts ${ }^{10}$. This screen identified a number of genes that were persistently expressed in pluripotent derivatives, and therefore suggestive of an early embryonic state, or genes that failed to be induced in pluripotent derivatives but were highly expressed in tissue derived cells. TDG was expressed significantly higher in neural progenitors generated from pluripotent stem cells as opposed to the same cell type derived from fetal brain (Figure 1A, shown in $\log 2$ scale).

The Allen Brain Atlas created by the Allen Institute provides gene expression data from various brain regions across both development and through adulthood. As shown in Figure 1B, $T D G$ is expressed most highly in the brain in utero, and then falls after birth and stays low throughout adulthood. The same was true for the Ten-Eleven Translocation (TET) family of dioxigenases ${ }^{7}$, suggesting that DNA demethylation is primarily performed in utero. It is also possible that DNA demethylation by TDG and TETs function is linked to proliferation, which is known to decrease at birth relative to that found in utero. Because of this and previous data suggesting TDG could potentially regulate the cell cycle, we stained neural progenitors made from human pluripotent stem cells or derived from tissue for TDG and Ki67. The cell cycle phase for this assay was determined based on a previously reported KI67 staining pattern within the nucleus ${ }^{11}$. TDG was also previously reported to be tightly regulated during the progression of the cell cycle as its level is rapidly downregulated by ubiquitination in the $\mathrm{S}$ phase of the cell cycle in cellular models such as HeLa and fibroblasts and re-expressed in $\mathrm{G} 2^{12}$. Here, we found a similar result, namely that TDG protein levels appear to correlate with G0/G1stages of the cell cycle (Figure 1C and D).

\section{Silencing TDG by siRNA}

To investigate the role of $T D G$ in early human development, we used siRNA mediated knock-down (KD) of $T D G$ in neural progenitor cells (NPCs) derived from hPSC (Figure 2A and B). To determine whether $T D G \mathrm{KD}$ led to expected changes in 5-carboxylcytosine (5caC) and 5-formylcytosine (5fC) DNA residues, immunostaining for these markers was performed. As expected, silencing TDG led to an increased intensity of $5 \mathrm{caC}$ and 5fC DNA, with no change in 5-Hydroxymethylcytosine (5hmC) DNA (Figure 2C).

RT-PCR for genes typical of the NPC state showed essentially no change in $T D G \mathrm{KD}$ cells (Figure 2D). Though downregulating TDG levels showed no influence on NPC identity, we further tested whether lower TDG levels affects differentiation. Four days post TDG KD treatment, NPCs were induced to further differentiate using the growth factor withdrawal method (removal of self-renewal supporting growth factors EGF, bFGF). Three weeks after induction of differentiation, we analyzed the percentage of MAP2/GFAP positive cells, which represent the differentiation expectancy towards the neuronal/glial lineage respectfully. We found that though the neural/ glial ratio remained similar, the total differentiated cell percentage was lower than in control (Figure 2E), indicating a failure to properly differentiate upon silencing of TDG. Typically, such a differentiation block would be due to aberrant differentiation or due to prolonged proliferative stimulus.

We also looked for gene expression changes following TDG-KD in NPCs by RNA-SEQ. 355 genes were differentially expressed 
A

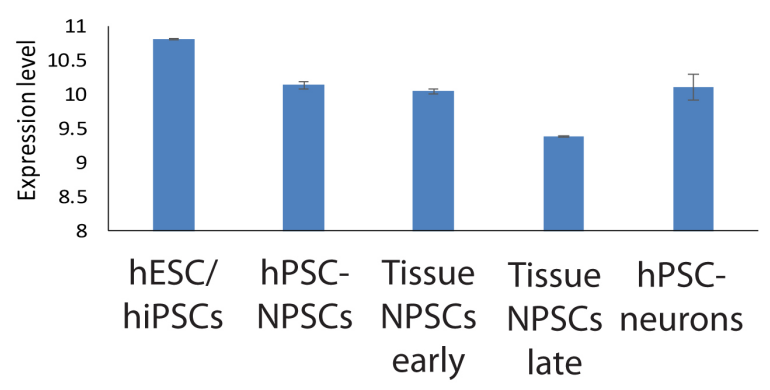

B expression of DNA Demethylases

in human brain
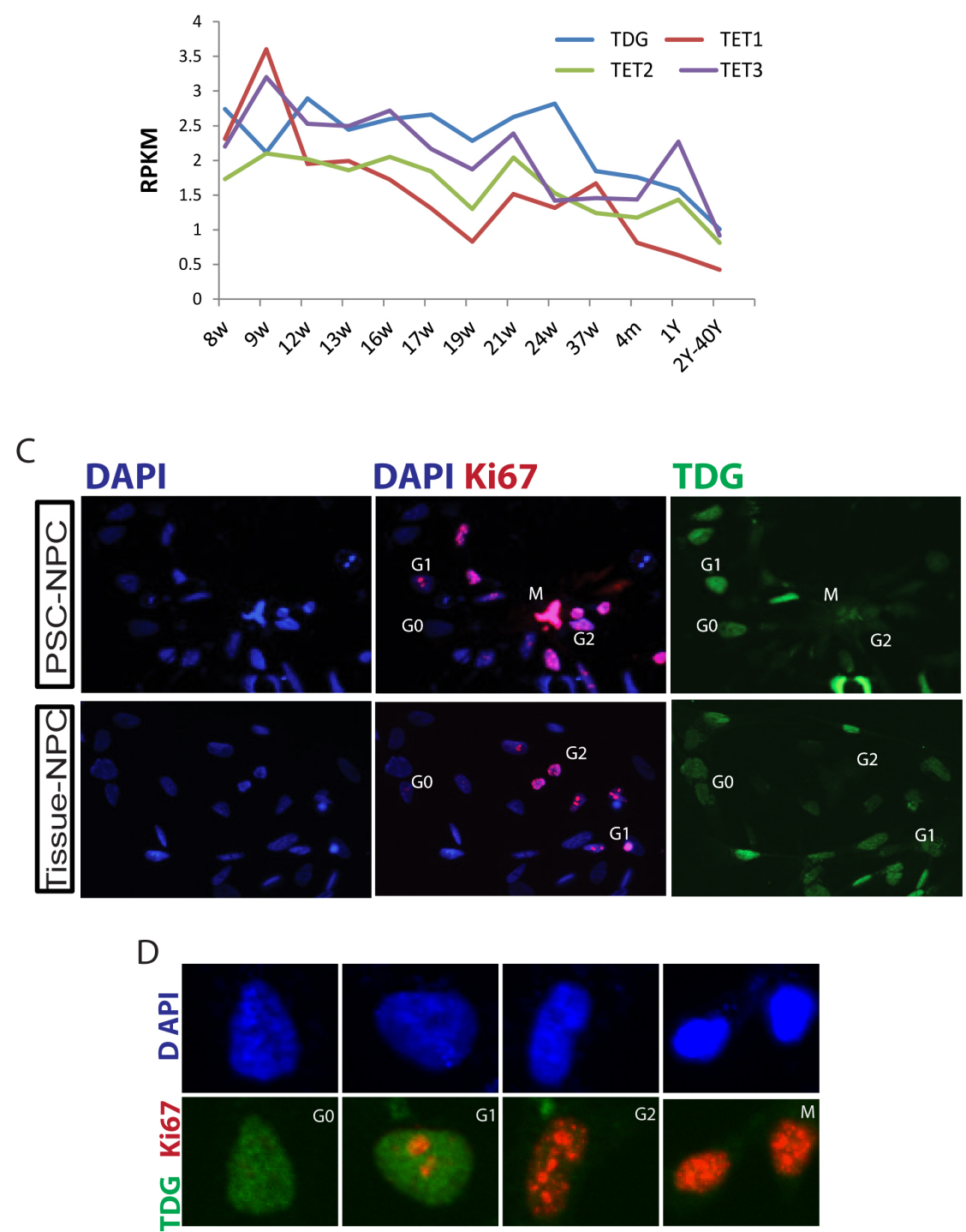

Figure 1. TDG is expressed during early human neuronal development. A, Average expression of the TDG microarray probe in hPCS, hPSC derived NPCs and neurons and tissue derived NPCs, adapted from 10. Data presented are the average of at least three independent samples and normalized by log2 according to 13. B. RNA-seq analyses for the expression of TDG, TET1, 2 and 3 adopted from the Allen Institute's Brainspan developmental transcriptome database displayed as log-scale reads per kilobase measured (log2 RPKM) across the developing human brain. C. Immunofluorescent (IF) staining for KI67 and TDG expression in NPCs derived from human pluripotent stem cells (PSC-NPCs) or human brain tissue (Tissue-NPCs). D, Magnified images (from panel C) of representative nuclei for different cell cycle stages. Images were taken at 20X magnification. 


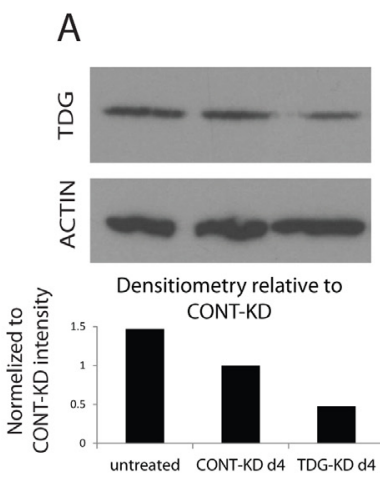

\section{B}
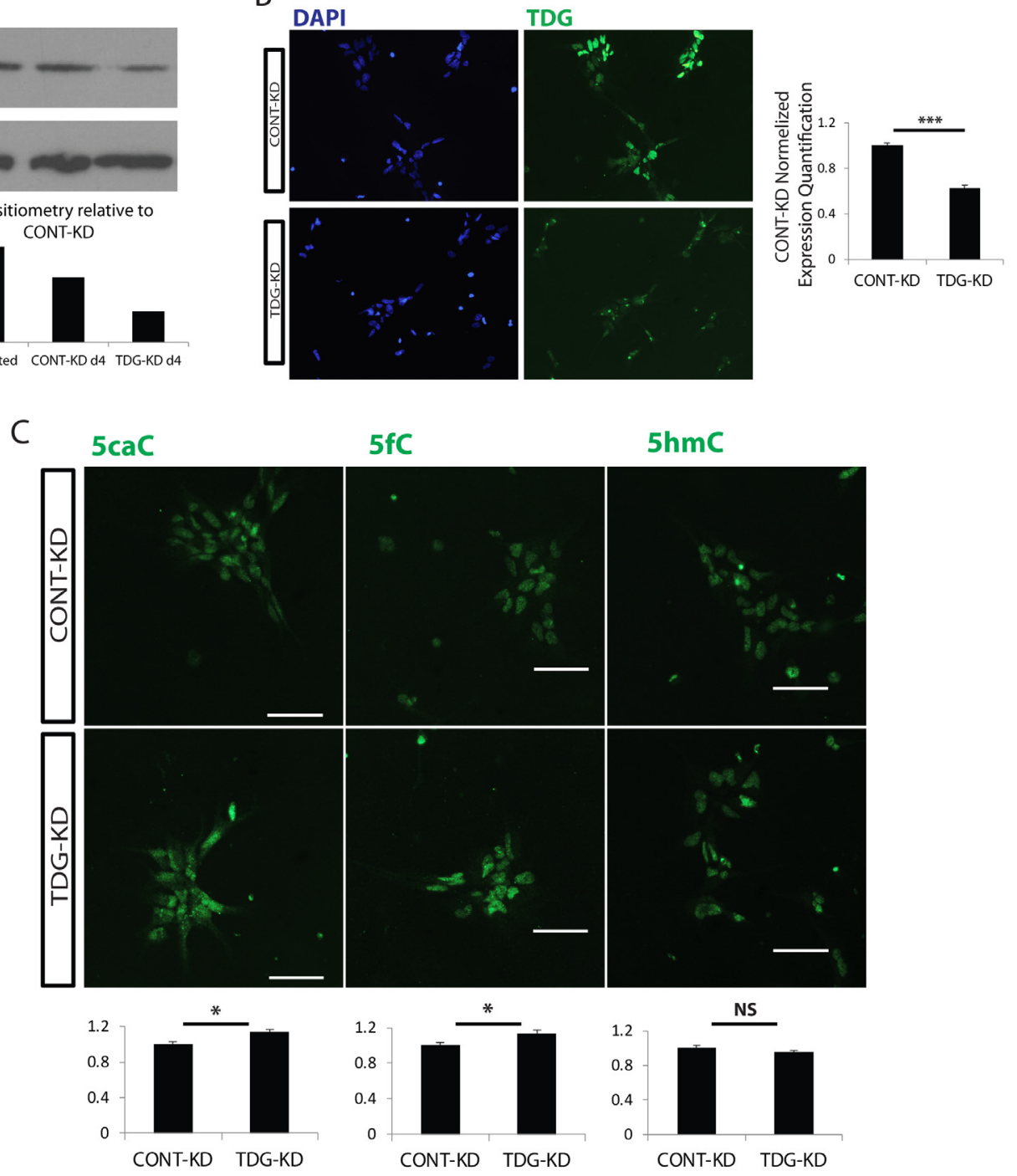

$\mathrm{E}$

MAP2/GFAP
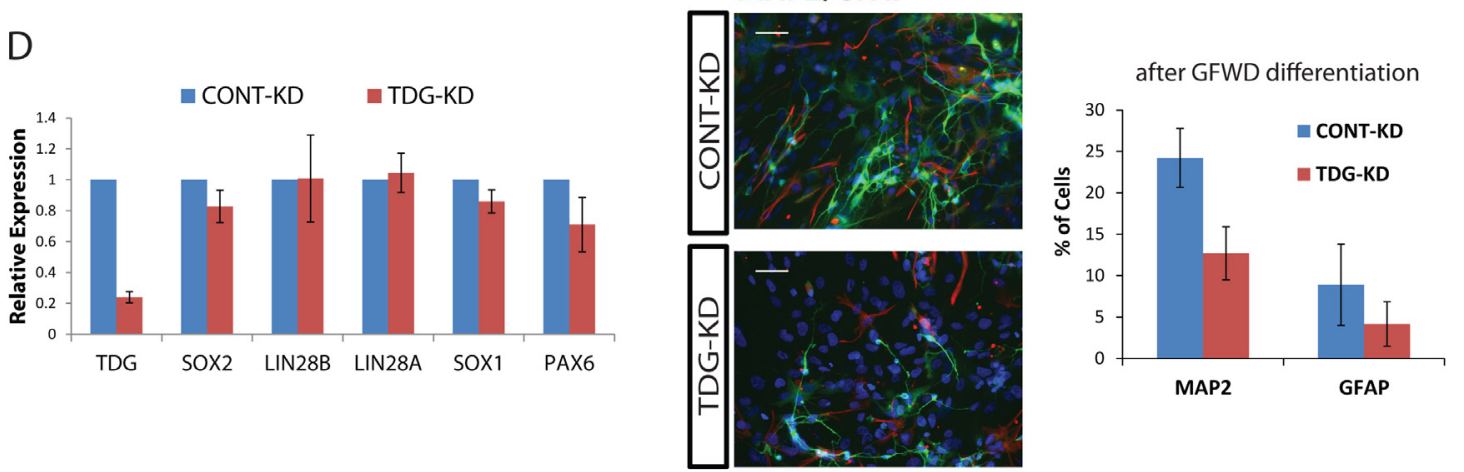

Figure 2. TDG downregulation in NPCs affects differentiation capacity. A, TDG protein expression level at day 4 post siRNA transfection, measured by Western blot (top). B, Immunostaining for TDG in NPCs following siRNA transfection, and quantification (right). C, Top: Representative immunofluorescence of DNA methylation modifications. Bars represent 50um. Bottom: ImageJ quantification of TDG-KD normalized to CONT-KD. Quantification was performed for over 100 nuclei across at least 5 images. Error bars represent standard error of the mean normalized to CONT-KD. D. Expression levels of NPC markers measured by qRT-PCR, normalized against the relative levels of GAPDH and compared to CONT-KD, error bars represent standard error of the mean of 3 knockdown experiments. E, 4 Days post siRNA transfection, NPCs were induced to terminally differentiate by growth factor withdrawal (GFWD). Left: representative IF of 3 Weeks neural differentiation. Efficiency measured by the ratio of percentage of MAP2 (neuron)/GFAP (glia). Bars represent 50 $\mu$ m. Right: quantification of $n=3$ from at least three separate knockdown/differentiation experiments. $p$-values were calculated with Student's t test: * $=p<0.05$, ns $=$ not significant. 
by 1.5 fold across 3 independent experiments (Figure $3 \mathrm{~A}$ ). Using the DAVID annotation tool ${ }^{14}$, we classified those genes into functional groups (Figure 3B). Of the most significantly enriched functional annotations identified, we found 34 cell cycle related genes. Among those, genes which are major players in mitosis, $C D K 1, C D K 10, S K P 2$ were upregulated. In contrast, other genes like $C D C 25 B$ and $C D K N 1 C$ (p57), which are inhibitors of cell cycle progression, were downregulated (Figure 3C).

To validate that silencing of $T D G$ by siRNA led to changes in DNA demethylation, we performed Methylase-assisted bisulfite conversion PCR (MAB-PCR) to probe for the presence of the $5 \mathrm{mC}$ and $5 \mathrm{hmC}$ in a gene whose expression changed upon siRNA-mediated knockdown of TDG. MAB-PCR takes advantage of an enzyme and bisulfite-conversion sequencing to identify the relative abundance of $5 \mathrm{caC}$ and $5 \mathrm{fC}$ nucleotides (Figure 4A). This allows for a measure of TDG activity, as TDG is known to use its glycosylase activity to finish the demethylation process to convert $5 \mathrm{caC}$ and $5 \mathrm{fC}$ to the fully demethylated state. To determine whether TDG activity can regulate the methylation and gene expression, we looked specifically at a gene whose expression was affected in TDG-KD cells. EGR1, the early growth response gene is known to be dynamically regulated by a variety of mechanisms, including DNA Methylation at an upstream CpG island (Figure 4B) ${ }^{15}$. We analyzed a segment of a $\mathrm{CpG}$ island upstream to the EGRI transcription start site (TSS site). This locus was chosen as it was reported to have the highest distribution of $5 \mathrm{fC}, 5 \mathrm{caC}$ around the TSS.

This analysis showed that silencing of $T D G$ by siRNA led to a dramatic accumulation of $5 \mathrm{caC}$ and $5 \mathrm{fC}$ in a $\mathrm{CpG}$ island directly upstream of the start site of EGRl transcription (Figure 4C and D). This experiment provided evidence that TDG not only regulates DNA demethylation, but also that this can influence gene expression. The proportion of genes differentially regulated by TDG-mediated DNA demethylation remains unclear until a genome-wide analysis can be performed.

We further tested whether TDG-KD in NPCs affects entrance into the cell cycle by Ki67 staining, and found that downregulating TDG resulted in a higher percentage of proliferating cells when this enzyme was knocked down (Figure 5A). Co-staining of Ki67 with TDG showed that TDG is downregulated with cell cycle progression, as higher TDG expression is observed in G0/early G1 cells, and downregulated with cell cycle progression (Figure 2D). We also measured cell cycle dynamics by Flow Cytometry (FACS) upon TDG silencing. This high-throughput method allowed for an accurate determination of the effect of siRNA on $T D G$, and showed that the proportion of cells in $\mathrm{S}$ phase was significantly decreased, while the proportion in G2/M was increased (Figure 5C). Taken together, it seems clear that TDG plays a role in human pluripotent stem cell cycle regulation.

\section{Development of FUCCI model for cell cycle analyses}

Despite all the analyses above, it was not clear whether silencing of $T D G$ affects the cell cycle through its ability to regulate the terminal step of DNA demethylation. It is formally possible that the DNA glycosylation activity of $T D G$ is used for other substrates besides methylated cytosine, for instance in DNA repair. It is also possible that another domain of TDG regulates cell cycle progression by another unknown mechanism. To attempt to link DNA demethylation by TDG to regulation of the cell cycle, we needed a system that could allow for simultaneous labeling of DNA demethylation intermediates and cell cycle markers. We generated hESCs which expressed the Fluorescence Ubiquitination Cell Cycle Indicator (FUCCI) transgene reporter system by lentiviral transduction ${ }^{16}$. In this system, cells which are in the G1 stage express Ctd1, which is conjugated to mCherry, while cells in S/G2 expressed Geminin which is conjugated to visible green protein mVENUS. Cells entering the DNA replication stage at the end of G1 express both markers and emit yellow light (Figure 6A). We first verified that the level of TDG was tightly regulated during cell cycle progression in hPSC as in other reported cell systems since hPSC display a unique cell cycle pattern. We found high levels of TDG in early G1 which are downregulated with cell cycle progression (Figure 6B). Interestingly, we found that $5 \mathrm{caC}$ and $5 \mathrm{fC}$ were both induced in early $\mathrm{S}$ phase cells, while $5 \mathrm{hmC}$ was reduced (Figure 6B) as was reported before. This indicates that the global state of DNA demethylation is tightly correlated to progression of the cell cycle. Furthermore, all these data on the effect of TDG on cell cycle serve to explain why silencing of $T D G$ led to defective neuronal and glial specification in NPCs (Figure 2D).

Dataset 1.TDG regulates cell cycle progression in human neural progenitors

http://dx.doi.org/10.5256/f1000research.13801.d201379

Complete dataset of all underlying data divided into folders based on relevant figures

\section{Discussion}

The data presented here confirm and extends previous findings that TDG and DNA demethylation can play a role in proper progression through the cell cycle. These results could be particularly relevant for the nervous system, where we provide evidence that TDG and TET mediated demethylation appears to diminish across development. This correlates with both proliferative rate and TDG expression, and could have important consequences to the rate of developmental progression. The big question remaining from this work is how DNA demethylation plays a role in progression of the cell cycle. When DNA is replicated it is thought that the new daughter strand is methylated according to the hemi-methylation pattern on the sister strand by maintenance DNA Methyltransferases (DNMT1). Less clear is what happens to portions of the genome that are hemi-methylated hydroxymethylated nucleotides. The change in proportions of $5 \mathrm{caC}$ and $5 \mathrm{fC}$ across the cell cycle could indicate that these modified nucleotides are simply erased through the action of TET and TDG enzymes, and then re-written. In this scenario, it is interesting that blocking $T D G$ appeared to promote the cell cycle rate, and could suggest that demethylation is a rate limiting step in cell cycle progression to ensure proper methylation of DNA in both daughter cells. 
A

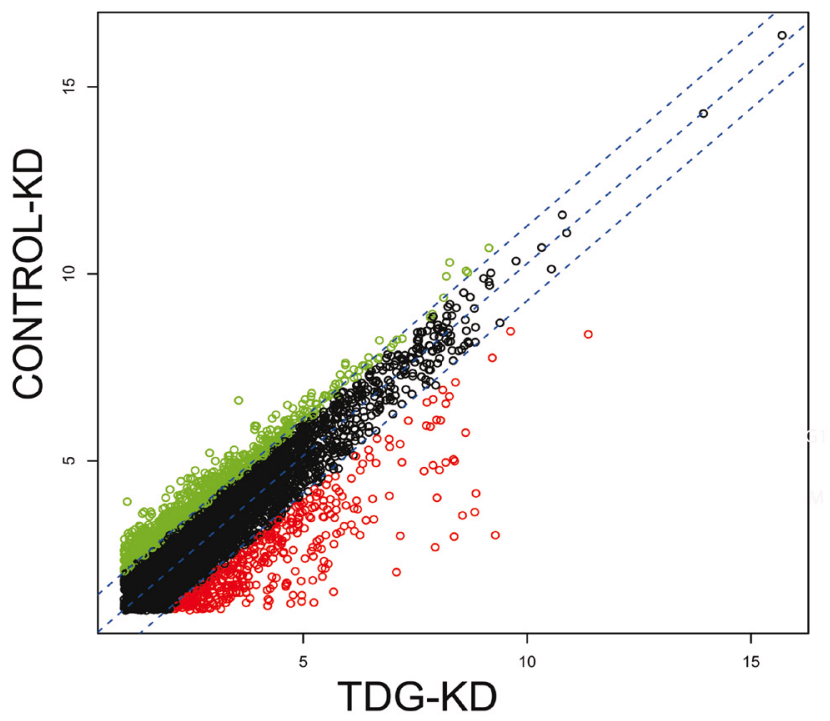

B

GO Term analysis of TDG-KD differentially expressed genes negative regulation of apoptosis

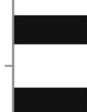

$2.75 \mathrm{e}-04$

cell activation

cell cycle

$-$

cytoskeleton

intracellular nonmembrane-bounded.

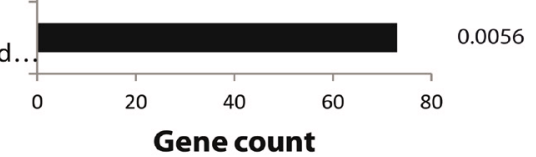

C

Cell cycle differentially expressed genes

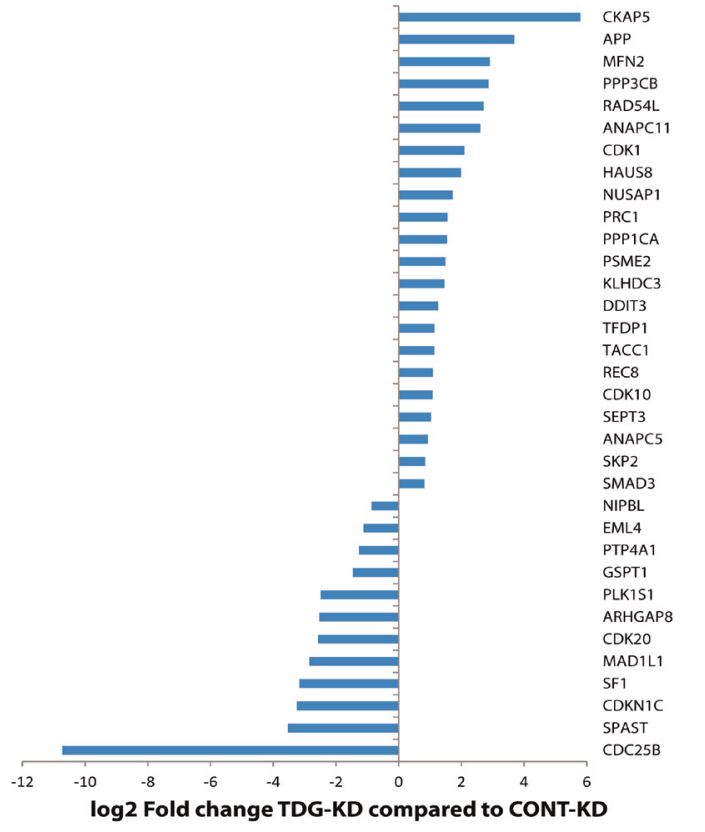

Figure 3. TDG-KD NPC differential gene expression analyzed by RNA-seq. A, Differential gene expression of $n=3$ siRNA knockdown experiments. Scatter plot of the group average FPKM (log2) for all genes mapped above the background cutoff, differentially expressed genes (over 1.5 fold change; $p<0.05$ ) are highlighted in red and green. B. Functional annotation of differentially expressed genes shows significant change in genes related to cell cycle, regulation of apoptosis and structural genes. C. Cell Cycle related differentially expressed list of genes and the relative fold change. 
A

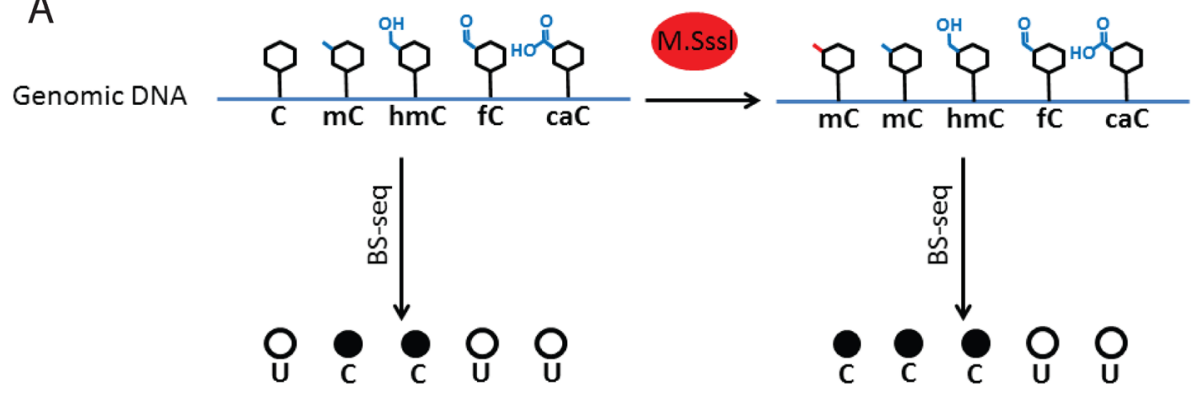

B

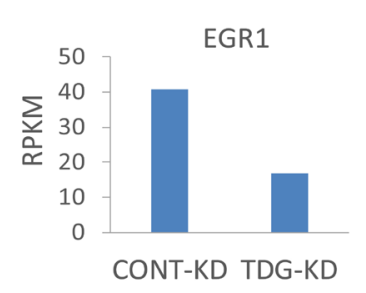

$\mathrm{D}$

$$
\text { C }
$$

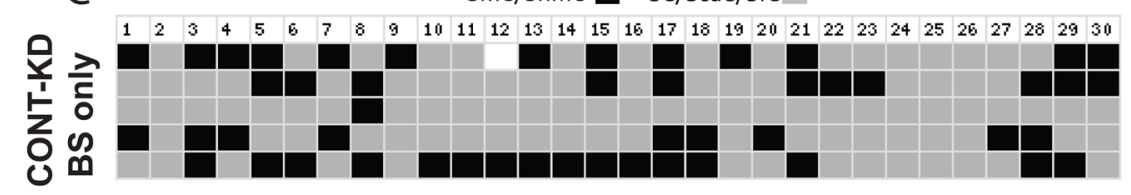

$5 \mathrm{c} / 5 \mathrm{mC} / 5 \mathrm{hmC} \square \quad 5 \mathrm{caC} / 5 \mathrm{fC}$
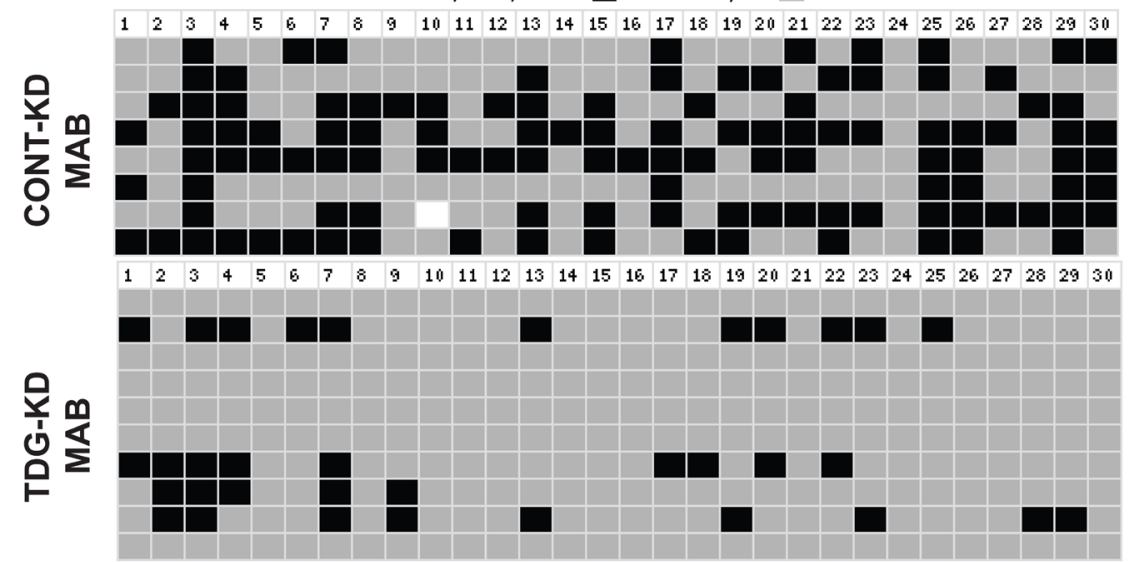
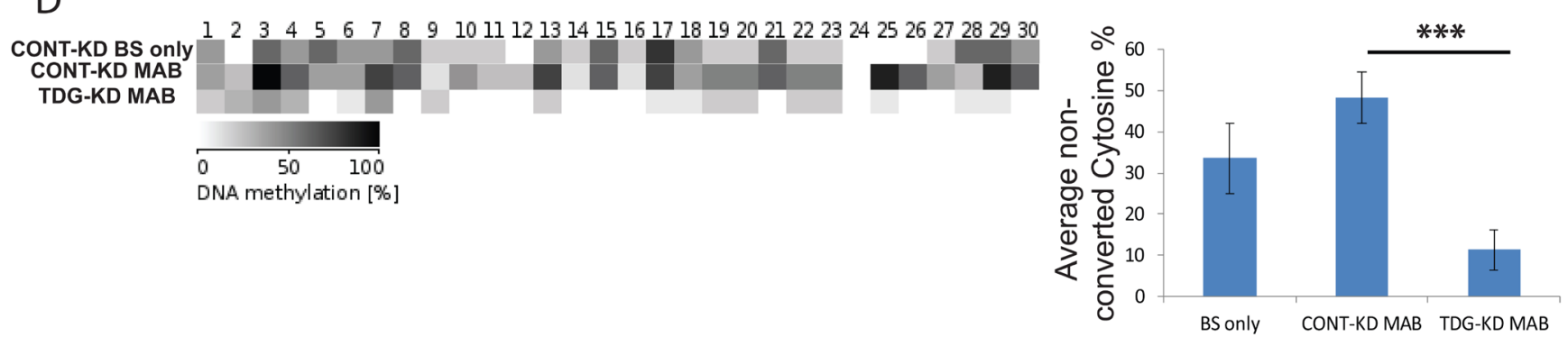

Figure 4.TDG downregulation results in elevation of $5 \mathrm{caC}, 5 \mathrm{fC}$ in a $\mathrm{CpG}$ island upstream to the EGR1 TSS site. A, Schematic illustration of the sequencing of methylase treated compared to non-treated bisulfite converted transcripts. B, EGR1 expression levels are downregulated following TDG knockdown as measured by RNA-seq (described in Figure 2). C, Sanger sequencing of the CpG island upstream to the EGR1 TSS following either bisulfite conversion (BS only; top) or MAB treatment (bottom two) shows higher abundance of $5 \mathrm{cAC}, 5 \mathrm{fC}$ in TDG deficient cells; numbers indicate CpG dinucleotide position. D. Summary visualization (left) and quantification (right) of the abundance of non-converted residues described in Figure 4C. Error bars represent standard error of the mean methylation level of at least 5 sequenced samples, $p$ values were calculated with Student's t test: ${ }^{\star \star *}=p<0.001$. 

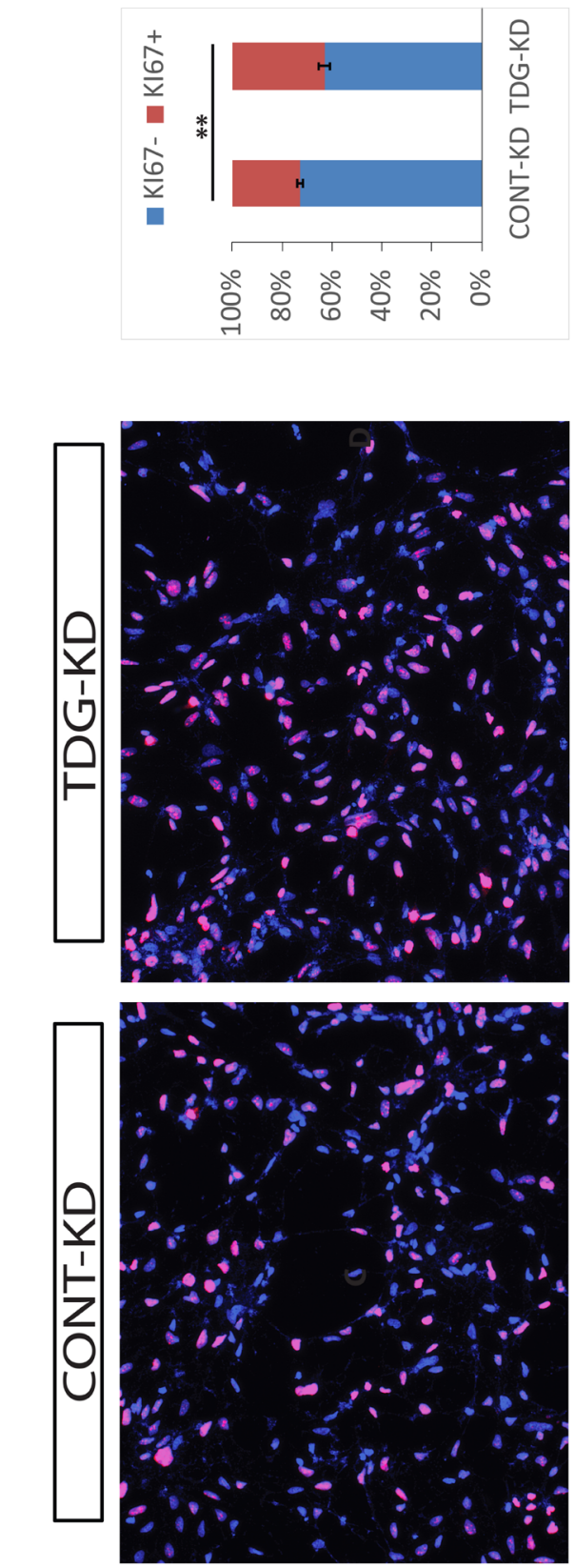

$\leftarrow$
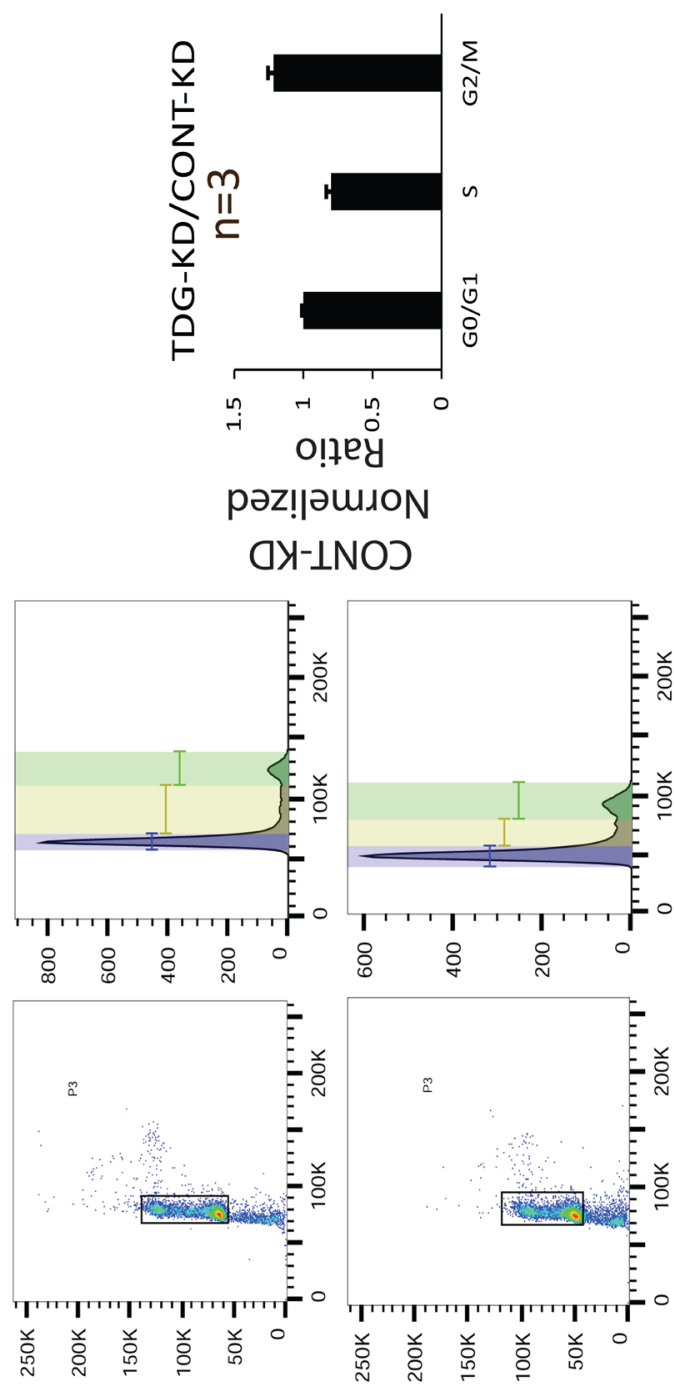

응

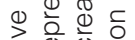

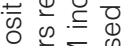

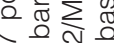

毛产

至

응 흐응

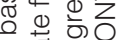

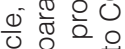

O)

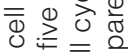

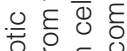

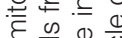

O)

迹 $8 \frac{\pi}{0} \overline{0}$

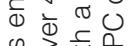

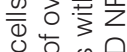

등드 $\frac{1}{5} \frac{1}{4}$

드유.

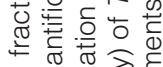

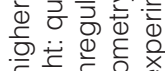

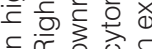

क लि

क्र

드은

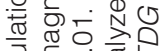

हैं

난

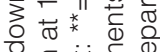

(1) ब

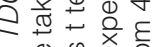

$<\frac{0}{0}$ 号

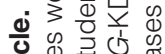

万人

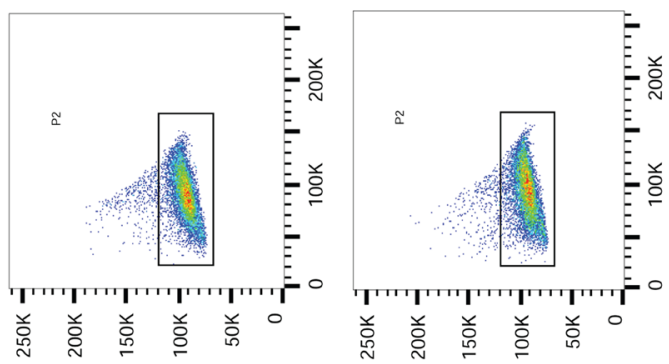

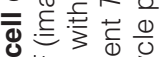

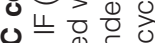

$\sum_{0}^{0} \frac{\pi}{5} \frac{0}{0} \overline{0}$

눙응ㅎㅁ

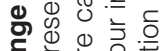

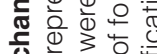

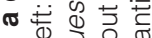

에

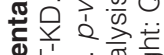

子之桴

है

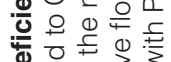

잉

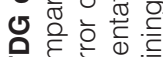

in 0 o

เค 웡

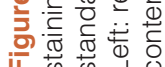


A

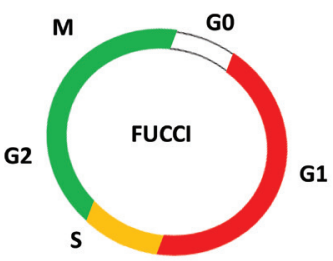

B
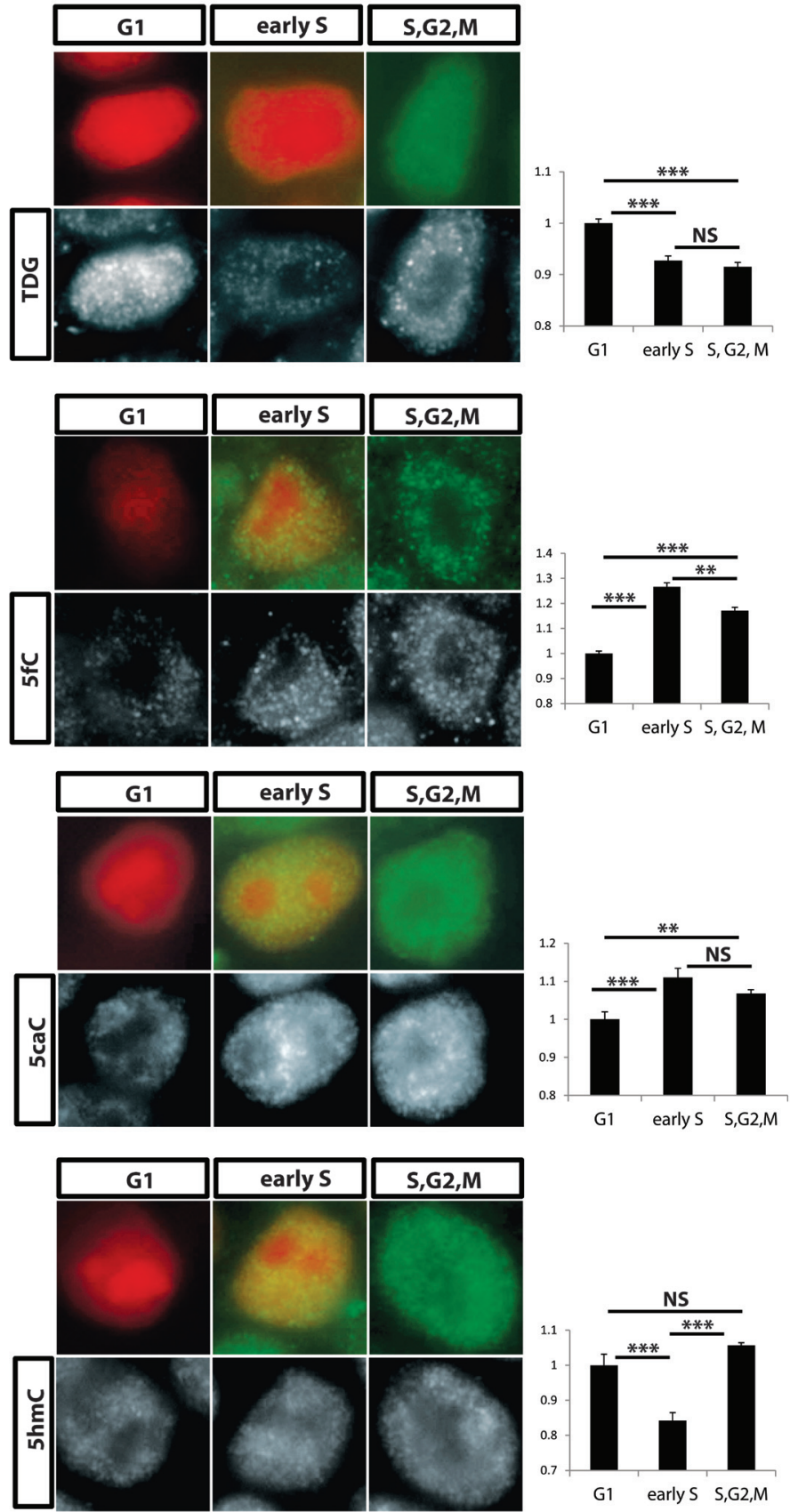

Figure 6. Methylation intermediate modifications level changes throughout the cell cycle. A, Illustration of the FUCCI cell cycle reporter system expression. B, Co-staining for particular cell cycle phase with antibody against either TDG or methylation intermediate modifications. Left: representative nucleotide for each cell cycle stage (Pics were taken using a 20X magnification and a cropped single nucleotide is presented) Right: intensity of staining was quantified using ImageJ for over 500 cells, values normalized to G1 (Y Axis) are presented. $p$ values were calculated with Student's t test: ${ }^{* *}=p<0.01,{ }^{* * *}=p<0.001$, ns $=$ not significant. 
Because of the difference in expression levels of $T D G$ between pluripotent and tissue derived NPCs (Figure 1A), we expected that silencing $T D G$ would have a positive effect on the progression of developmental maturity of the NPCs. The LIN28/let-7 circuit was previously shown to be differentially regulated between NPCs born from pluripotent stem cells versus those derived from tissues, and resolution of this discrepancy was sufficient to advance the developmental maturity of NPCs in that context ${ }^{17}$. When the expression of $T D G$ was brought down to a level similar to that seen in tissue derived NPCs, instead of advancing developmental maturation, the cells appeared to be unable to efficiently differentiate (Figure 2). This was presumably due to the increased rate of proliferation of the NPCs, a cell type where forced exit of the cell cycle is known to induce differentiation. Therefore, experimentally regulating $T D G$ levels does not facilitate differentiation from pluripotent stem cells, as was the case with experimental downregulation LIN28. Perhaps the more interesting result from this work is that pluripotent derivatives probably need to silence $T D G$ expression or activity at a more developmentally appropriate time point to proceed through proper development.

\section{Methods}

Tissue culture and TDG knockdown

H9 hESCs and XFIPS2 were used in this study in accordance with the UCLA Embryonic Stem Cell Research Oversight committee (ESCRO, 2006-019-11A) and the Institutional Biosafety Committee (IBC). This work was specifically described in our ESCRO application (2006-019-11A), and approved on an annual basis by the committee. This work is considered not human subjects research by the UCLA IRB.

Cells were cultured in feeder free conditions on Matrigel (Corning) using mTeSR1 (Stem Cell Technologies) and passaged mechanically or with collagenase every 4-5 days. NPCs differentiation was performed as described previously (10). Briefly, for rosette induction, $80 \%$ confluent hPCS were cultured in DMEM/ F12 with N2 and B27 supplements (Invitrogen), $20 \mathrm{ng} / \mathrm{ml}$ basic fibroblast growth factor (bFGF; R\&D Systems), $1 \mu \mathrm{M}$ retinoic acid (Sigma), $1 \mu \mathrm{M}$ Sonic Hedgehog Agonist (Purmorphamine;

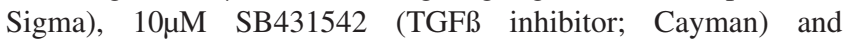
$0.1 \mu$ M LDN193189 (BMP receptor type 1 inhibitor; Cayman). Small molecules were resuspended according to each manufacturer instructions. After about a week of culture neural-like rosettes were mechanically picked and expanded in NPC maintenance medium: DMEM/F12 supplemented with N2/B27, bFGF and $500 \mathrm{ng} / \mathrm{ml}$ epidermal growth factor (EGF; GIBCO). For further differentiation, the growth factors bFGF and EGF were withdrawn from the media (GFW) and cultured for 3 weeks. TDG and control knockdown in NPCs was performed using a unique 27-mer siRNA duplexes (Trilencer, Origene) at a final concentration of $20 \mathrm{nM}$ using Lipofectamine RNAiMAX transfection reagent (Invitrogen).

\section{Immunofluorescence and Western Blot}

Immunofluorescent staining was performed using standard $\operatorname{protocol}^{10,17}$. Briefly, cover slips were fixed with $4 \%$ PFA in
PBS for $20 \mathrm{~min}$, washed and then permeabilized and blocked in $10 \%$ donkey serum, $0.01 \%$ Triton in PBS for 1 hour. Primary antibodies in 5\% donkey serum were incubated for 1-2 hours at room temperature following $3 \mathrm{X}$ wash in PBST and incubation with conjugated secondary antibody for 1 hour in room temperature. After $3 \mathrm{X}$ wash with PBST cover slips were incubated with $300 \mathrm{nM}$ DAPI final concertation in PBST for $3 \mathrm{~min}$ in room temperature (dark), followed with $3 \mathrm{X}$ wash with PBST. Antibodies used include the following: polyclonal rabbit anti-TDG 1:100(Atlas; HPA052263); polyclonal chicken anti-GFAP 1:1000(Abcam; ab4674); mouse monoclonal antiMAP2 1:500 (Abcam, ab11267), polyclonal rat anti-KI67 1:100 (eBioscience; 14-5698). For methylation modifications, permeabilized cells were denatured with $2 \mathrm{~N} \mathrm{HCl}$ for $15 \mathrm{~min}$ and then neutralized with $100 \mathrm{mM}$ Tris- $\mathrm{HCl}(\mathrm{pH}$ 8.5) for $10 \mathrm{~min}$ before blocking. The following Active-Motif Antibodies were used: rabbit anti $5 \mathrm{hmC} 1: 100(39770)$; rabbit anti-5fC 1:2500 (61223); rabbit anti-5caC 1:1000 (61225). Image analysis and quantification was performed using ImageJ version 1.50i with the same threshold for each channel for all samples. Western Blot analysis was performed using standard procedures as described (Lowry et al., 2005) antibodies used were rabbit anti-TDG as described above and mouse anti-Actin 1:1000 (Santa Cruz Biotechnology, sc-47778).

RT-PCR Analysis. Total RNA was extracted using an RNeasy Mini Kit (QIAGEN). cDNA synthesis was performed using the Superscript III first-strand cDNA synthesis kit (Invitrogen). Real-time PCR was performed in triplicate using the SYBR green real-time PCR MIX (Roche) in the Roche lightcycler 480 machine. Run was performed for 50 cycles and analysis was performed in Microsoft Excel 2013 using the 2- $\Delta \Delta \mathrm{CT}$ method.

\section{RNA-Seq}

Total RNA was extracted using an RNeasy Mini Kit (QIAGEN). Libraries were constructed according to manufacturer instructions (TruSeq Stranded Total RNA with Ribo-Zero; Illumina). Following second strand PCR amplification, 200bp sized libraries were excised from agarose gel and pooled together in $10 \mathrm{mM}$ concentration each. Samples were sequenced using Illumina HiSeq2000 on single-end 50-bp reads and aligned to human reference genome ( $\mathrm{Hg} 19)$ using Tophat (version 2.0.6) ${ }^{18}$. Processing using Cufflinks and Cuffdiff was performed to obtain differential fragments per kilobase of transcript per million mapped reads (FPKM) ${ }^{18}$. Three biological replicates (i.e. 3 separate knockdown experiments in different PSC clones) were grouped together. Further analysis was performed using the cummeRbund suite (v2.0.0). Functional annotation was performed using DAVID (V6.7) ${ }^{14}$.

\section{Cell cycle analysis}

Following trypsin dissociation, knocked-down NPCs were fixed overnight in $70 \%$ ethanol at $-20^{\circ} \mathrm{C}$. Fixed cells were then stained for half an hour at room temperature in the dark, with Propidium Iodide (PI) for a final concertation of $50 \mu \mathrm{g} / \mathrm{ml}$ supplemented with RNAse (final $1 \mu \mathrm{g} / \mathrm{ml}$ ). DNA content was analyzed on BD-Biosciences LSR-II flow cytometer and cell 
cycle phases were determined using the FlowJo cell cycle module (version 7.6.5).

\section{MAB-PCR}

Genomic DNA was extracted using the DNeasy Blood \& Tissue Kit (Qiagen; 69506). One $\mu$ g genomic DNA was treated by M.SssI (New England Biolabs; M0226s) in a $50 \mu \mathrm{l}$ reaction for three rounds. For each round DNA was incubated with 4 Units of M.SssI CpG methyltransferase (NEB), supplemented with $160 \mathrm{mM}$ final S-Adenosyl methionine for 3 hours at $37^{\circ} \mathrm{C}$. At the end of each round DNA was cleaned using phenol/chloroform extraction. Bisulfite conversion was performed using the EpiTect Bisulfite Kit (QIAGEN; 59104) and then selected loci was PCR amplified with KAPA HiFi Hotstart Uracil+ DNA polymerase (KAPABiosystems). The resulting PCR product was cloned into the TOPO-Blunt (Invitrogen) vector, and sent to Laragen for Sanger sequencing (GeneWiz). Analysis and visualization of sequence reads was done using the online BISMA tool.

\section{FUCCI cell line generation}

The FUCCI reporter lentiviral plasmids, pCSII-EF-mCherryhCdt1(30/120) and pCSII-EF-mVenus-hGeminin(1/110) were a generous gift of Dr. Atsushi Miyawaki (RIKEN Brain Science Institute, Saitama, Japan). Lentiviral virions were generated in $293 \mathrm{~T}$ cells using standard protocols as previously described $^{13}$ followed by concentration with Amicon Ultra-15 centrifugal units (100K; Millipore). hPSC were single celled with TryplE (Thermo) and re-plated $24 \mathrm{~h}$ prior to infection supplemented with $10 \mu \mathrm{M}$ Rho-associated kinase (ROCK) inhibitor Y27632 (Stemgent). Cells were first infected with one reporter lentivirus particles for overnight infection. Cells were washed with fresh medium and grown for 2- 3 passages for recovery and expansion. Next, we FACS sorted using FacsARIA (Becton Dickinson) the cells for the corresponding reporter to ensure that all cells are infected. Briefly: cells from a whole 6 well plate were treated with ROCK inhibitor for one hour, single celled using trypLE and re-suspended in PBS. After sorting cells were a re-plated for recovery for 5-7 days and then

We infected the cells with the second reporter using that same procedure followed by a second FACS sorting for the reporter.

\section{Statistical analysis}

Student's t-test was performed using GraphPad 6.01. Results were judged to be significant if the $p$-value was $<0.05$. All other statistical analysis described in this study were performed using Microsoft Excel 2013

\section{Data availability}

Dataset 1: TDG regulates cell cycle progression in human neural progenitors. Complete dataset of all underlying data divided into folders based on relevant figures. 10.5256/ f1000research.13801.d201379 ${ }^{19}$

\section{Competing interests}

No competing interests were disclosed.

\section{Grant information}

This work was supported by NIH (P01GM9913), Allen Distinguished Investigator award from the Allen Frontiers Group to WEL, A CIRM Basic Biology Award (RT-2), and pilot support from the BSCRC at UCLA (Rose Hills Scholar Award).

The funders had no role in study design, data collection and analysis, decision to publish, or preparation of the manuscript.

\section{Acknowledgements}

We would like to acknowledge the support of various core facilities and their staff at the core facilities sponsored by the Eli and Edythe Broad Center for Regenerative Medicine (EEBCRC) including: Flow Cytometry, Genomics, and the Stem Cell Cores.
1. Kohli RM, Zhang Y: TET enzymes, TDG and the dynamics of DNA demethylation. Nature. 2013; 502(7472): 472-479. PubMed Abstract | Publisher Full Text | Free Full Text

2. Sen GL, Reuter JA, Webster DE, et al.: DNMT1 maintains progenitor function in self-renewing somatic tissue. Nature. 2010; 463(7280): 563-567. PubMed Abstract | Publisher Full Text | Free Full Text

3. Flinders $\mathrm{C}$, Lam L, Rubbi L, et al:: Epigenetic changes mediated by polycomb repressive complex 2 and E2a are associated with drug resistance in a mouse model of lymphoma. Genome Med. 2016; 8(1): 54 PubMed Abstract | Publisher Full Text | Free Full Text

4. Mikkelsen TS, Ku M, Jaffe DB, et al:: Genome-wide maps of chromatin state in pluripotent and lineage-committed cells. Nature. 2007; 448(7153): 553-560. PubMed Abstract | Publisher Full Text | Free Full Text

5. Guenther MG, Levine SS, Boyer LA, et al:: A chromatin landmark and transcription initiation at most promoters in human cells. Cell. 2007; 130(1): $77-88$.

PubMed Abstract | Publisher Full Text | Free Full Text

6. Kristensen DG, Nielsen JE, Jørgensen A, et al:: Evidence that active demethylation mechanisms maintain the genome of carcinoma in situ cells hypomethylated in the adult testis. Br J Cancer. 2014; 110(3): 668-678. PubMed Abstract | Publisher Full Text | Free Full Text

7. Kinney SR, Pradhan S: Ten eleven translocation enzymes and 5-hydroxymethylation in mammalian development and cancer. Adv Exp Med Biol. 2013; 754: 57-79.

PubMed Abstract | Publisher Full Text

8. Cortázar D, Kunz C, Selfridge J, et al:: Embryonic lethal phenotype reveals a function of TDG in maintaining epigenetic stability. Nature. 2011; 470(7334): 419-423.

PubMed Abstract | Publisher Full Text

9. Rai K, Huggins IJ, James SR, et al:: DNA demethylation in zebrafish involves the coupling of a deaminase, a glycosylase, and gadd45. Cell. 2008; 135(7): 1201-1212.

PubMed Abstract | Publisher Full Text | Free Full Text

10. Patterson M, Chan DN, Ha I, et al:: Defining the nature of human pluripotent stem cell progeny. Cell Res. 2012; 22(1): 178-193. PubMed Abstract | Publisher Full Text | Free Full Text

11. Braun N, Papadopoulos T, Müller-Hermelink HK: Cell cycle dependent distribution of the proliferation-associated $\mathrm{Ki}-67$ antigen in human embryonic 
lung cells. Virchows Arch B Cell Pathol Incl Mol Pathol. 1988; 56(1): 25-33. PubMed Abstract | Publisher Full Text

12. Wheldon LM, Abakir A, Ferjentsik Z, et al:: Transient accumulation of 5carboxylcytosine indicates involvement of active demethylation in lineage specification of neural stem cells. Cell Rep. 2014; 7(5): 1353-1361. PubMed Abstract | Publisher Full Text

13. Germanguz I, Listgarten J, Cinkornpumin J, et al.: Identifying gene expression modules that define human cell fates. Stem Cell Res. 2016; 16(3): 712-724. PubMed Abstract | Publisher Full Text | Free Full Text

14. Huang da W, Sherman BT, Lempicki RA: Systematic and integrative analysis of large gene lists using DAVID bioinformatics resources. Nat Protoc. 2009; 4(1): 44-57.

PubMed Abstract | Publisher Full Text

15. Penner MR, Parrish RR, Hoang LT, et al:: Age-related changes in Egr1 transcription and DNA methylation within the hippocampus. Hippocampus.
2016; 26(8): 1008-1020.

PubMed Abstract | Publisher Full Text | Free Full Text

16. Singh $\mathrm{AM}$, Trost $\mathrm{R}$, Boward $\mathrm{B}$, et al.: Utilizing $\mathrm{FUCCl}$ reporters to understand pluripotent stem cell biology. Methods. 2016; 101: 4-10.

PubMed Abstract | Publisher Full Text | Free Full Text

17. Patterson M, Gaeta X, Loo K, et al.: let-7 miRNAs can act through notch to regulate human gliogenesis. Stem Cell Reports. 2014; 3(5): 758-73. PubMed Abstract | Publisher Full Text | Free Full Text

18. Trapnell C, Roberts A, Goff L, et al.: Differential gene and transcript expression analysis of RNA-seq experiments with TopHat and Cufflinks. Nat Protoc. 2012; 7(3): 562-578.

PubMed Abstract | Publisher Full Text | Free Full Text

19. Germanguz I, Park J, Cinkornpumin J, et al.: Dataset 1 in: TDG regulates cell cycle progression in human neural progenitors. F1000Research. 2018. Data Source 


\title{
Open Peer Review
}

\section{Current Peer Review Status: ? ?}

\section{Version 1}

Reviewer Report 02 November 2018

https://doi.org/10.5256/f1000research.15003.r38594

(C) 2018 Bellacosa A et al. This is an open access peer review report distributed under the terms of the Creative Commons Attribution License, which permits unrestricted use, distribution, and reproduction in any medium, provided the original work is properly cited.

\author{
Rahul Prasad \\ Fox Chase Cancer Center, Philadelphia, PA, USA \\ Timothy Yen \\ Fox Chase Cancer Center, Philadelphia, PA, USA
}

\author{
Alfonso Bellacosa \\ Fox Chase Cancer Center, Philadelphia, PA, USA
}

13/11/2018: This referee report has been updated from a Not Approved to an Approved with Reservations, and an additional sentence added, to reflect additional feedback from the referees after their report was published.

Germanguz et al. investigate the role of TDG in the differentiation and proliferation of human neural progenitor cells using RNA interference, RT-PCR, bisulfite sequencing, and cell cycle profiling with the FUCCI system. They show that TDG knockdown, using siRNA and assessed by immunofluorescence and supported by increased levels of $5 \mathrm{caC}$ and $5 \mathrm{fC}$ but not $5 \mathrm{hmC}$, correlates with an overall decrease in proportion of differentiated cells (both neurons and glia) following induction, in contrast to the authors' expectation of increased developmental maturity following TDG knockdown. RT-PCR data show expression of neural progenitor cell markers to be unaffected by TDG knockdown. The authors then investigate cell cycle changes using FACS following TDG knockdown and report an increased fraction of G2/M cells. The FUCCI cell cycle reporter system was used to show that TDG levels are decreased outside of G1. Methylation-assisted bisulfite sequencing (MAB-seq) was used to show evidence of changes in methylation intermediate modification levels in a putative promoter region of EGR1. The authors conclude that the reduction of TDG expression induces cell cycle specific changes that result in increased proliferation and reduced differentiation of neural progenitor cells. Overall the study uses a strong combination of experimental methods to show interesting findings but is likely a few experiments short of adding to the growing narrative involving TDG, demethylation, and cellular differentiation.

One point the authors do not account for is the potential for reprogramming of neural progenitor cells to different, undifferentiated progenitors. DNMT3B knockdown has been shown to cause an increase in neural crest cell markers, hypomethylation at the Sox 10 promoter region, and 
ultimately prolonged neural crest emigration ${ }^{1}$. Therefore it seems important to confirm that the neural progenitor cells that failed to fully differentiate remained in the neural cell lineage instead of reprogramming to neural crest precursors - if reprogramming did occur this would be a significant finding.

The cell cycle data are not clear; there seems to be a discrepancy between the marked effect of TDG knockdown as assessed by Ki67 staining (Fig. 5A), which suggests an increased fraction of proliferating cells, and the rather subtle effect as assessed by FACS (Fig. 5B). In particular, the authors should show the percent of cells in G1, $\mathrm{S}$ and G2M by FACS in control and TDG knockdown. Also, the authors should clarify why the overall DNA content appears to be reduced in TDG knockdown cells.

The reported increased fraction of G2/M cells following TDG knockdown using FACS merits further investigation. The use of propidium iodide prevents noting a distinction between increased proliferation (increased mitotic cells) or if the cells are simply arrested in $\mathrm{G} 2$. This can be resolved by using DAPI with a mitotic marker such as phospho-histone H3.

Additionally, the authors do not investigate the effects of TDG knockdown using the FUCCI reporter system. This seems to be a technically feasible experiment that would serve as an important point in the study's overall narrative linking TDG effects to the cell cycle.

The use of EGR1 as an example of methylation impacting gene expression is a point of concern. Selection of EGR1 as a gene of interest appears to be based on a single reference demonstrating methylation dependent expression in a rat model. Selection of a gene with a more established methylation dependent promotor region, such as $\operatorname{Pax} 6$, to compare with the expression profile would be a better indicator of whether TDG knockdown affects differentiation ${ }^{2}$. We would argue that the authors should show changes in methylation intermediate levels by TDG knockdown, using MAB-seq, in more than a single gene. A minimum of three genes would seem to be appropriate to convincingly show an effect of TDG on gene expression via changes in methylation intermediates.

The following points would be helpful to be addressed:

1. The reduction of $5 \mathrm{hmC}$ levels in early $\mathrm{S}$ phase, as demonstrated in figure $6 \mathrm{~B}$ is mentioned as previously reported but without citation in the main text.

2. In Figure $6 \mathrm{~B}, 5 \mathrm{hmC}$ levels are shown to reduce in early $\mathrm{S}$ relative to $\mathrm{G} 1$, consistent with the coinciding increase in $5 \mathrm{fC}$ and $5 \mathrm{caC}$ levels. However, while $5 \mathrm{fC}$ and $5 \mathrm{caC}$ levels remain elevated in S, G2, and M compared to G1, $5 \mathrm{hmC}$ levels return to G1 levels and statistically higher levels than early $\mathrm{S}$ phase. This is a paradoxical finding and should be addressed.

3. In the methodology described for MAB-seq, the use of phenol/chloroform extraction is noted. This method has an established risk of sensitizing DNA to oxidation and should be addressed $^{3}$, and therefore artifactually increase the levels of the oxidized cytosine species $5 \mathrm{fC}$ and $5 \mathrm{caC}$. It is recommended that alternative methods of extracting DNA are used after each M.SssI treatment, such as Agencourt AMPure XP Beads ${ }^{4}$.

Minor points:

Normalized is mispelled in the figure legends. 
Several references are missing in the Introduction and throughout the paper, such as:

Cortellino et al. (2011) on TDG knockout and embryonic lethality.

Hardeland et al (2007), Slenn et al. (2014) and Shibata et al. (2014), on the decrease of TDG levels in S-phase.

In the Introduction, what are the references for the sentence: "Loss of methylation in specific locations..."?

In Fig. 2E what are the p-values for the differentiation? In particular, is the difference in GFAPpositive cells between control and TDG-KD significant?

In the MAB-seq results, can the authors clarify the sentence: "This locus was chosen as it was reported (which reference?) to have the highest distribution of $5 \mathrm{fC}, 5 \mathrm{caC}$ around the TSS"?

For the MAB-seq analysis in Fig. 4, it would be useful to have a schematic map showing the relationship of the CpG island to the TSS.

In the paragraph on the FUCCI results, "DNA glycosylation activity of TDG" should be changed to "DNA glycosylase activity of TDG".

In the paragraph on the FUCCI results, it is not clear whether the FUCCI system was employed in hESC or hPSC cells.

In the paragraph on the FUCCI results, the last sentence: "Furthermore, all these data..." is not clear and should be rewritten.

The Discussion in the present form is a bit unclear, and should be rewritten, e.g. the last sentence is particularly imprecise. Also, references should be added to the Discussion.

In Fig. $4 \mathrm{C}$, change " $5 \mathrm{C}$ " to " $\mathrm{C}$ ".

\section{References}

1. Hu N, Strobl-Mazzulla PH, Simoes-Costa M, Sánchez-Vásquez E, et al.: DNA methyltransferase 3B regulates duration of neural crest production via repression of Sox10.Proc Natl Acad Sci U S A. 2014; 111 (50): 17911-6 PubMed Abstract | Publisher Full Text

2. Verma N, Pan H, Doré LC, Shukla A, et al.: TET proteins safeguard bivalent promoters from de novo methylation in human embryonic stem cells.Nat Genet. 2018; 50 (1): 83-95 PubMed Abstract | Publisher Full Text

3. Claycamp H: Phenol sensitization of DNA to subsequent oxidative damage in 8-hydroxyguanine assays. Carcinogenesis. 1992; 13 (7): 1289-1292 Publisher Full Text

4. Neri F, Incarnato D, Krepelova A, Parlato $C$, et al.: Methylation-assisted bisulfite sequencing to simultaneously map $5 \mathrm{fC}$ and $5 \mathrm{caC}$ on a genome-wide scale for DNA demethylation analysis.Nat Protoc. 11 (7): 1191-205 PubMed Abstract | Publisher Full Text

Is the work clearly and accurately presented and does it cite the current literature? Partly

Is the study design appropriate and is the work technically sound? Partly

Are sufficient details of methods and analysis provided to allow replication by others? Partly

If applicable, is the statistical analysis and its interpretation appropriate? Yes

Are all the source data underlying the results available to ensure full reproducibility? 
Yes

Are the conclusions drawn adequately supported by the results?

Partly

Competing Interests: No competing interests were disclosed.

We confirm that we have read this submission and believe that we have an appropriate level of expertise to confirm that it is of an acceptable scientific standard, however we have significant reservations, as outlined above.

Reviewer Report 14 June 2018

https://doi.org/10.5256/f1000research.15003.r34353

(c) 2018 Ruzov A et al. This is an open access peer review report distributed under the terms of the Creative Commons Attribution License, which permits unrestricted use, distribution, and reproduction in any medium, provided the original work is properly cited.

\section{Alexey Ruzov}

Division of Cancer and Stem Cells, Centre for Biomolecular Sciences (CBS), School of Medicine, University of Nottingham, Nottingham, UK

\section{Abdulkadir Abakir}

Division of Cancer and Stem Cells, Centre for Biomolecular Sciences (CBS), School of Medicine, University of Nottingham, Nottingham, UK

The manuscript by Germanguz et al. investigates potential roles of active DNA demethylation and the component of DNA base excision repair (BER) pathway, thymine DNA glycosylase (TDG) in cell cycle progression using human pluripotent stem cells (hPSCs) as a model. The authors first examined the expression levels of TDG in hPSCs, hPSC-derived neuronal progenitor cells (NPCs) as well as in the tissue-derived NPCs. Although the authors report a significant increase in expression of TDG in the hPSC-derived NPCs compared to the NPCs derived from tissues, it is unclear how comparable these two NPCs derivatives are and, therefore, the rationale behind this comparison is not fully clear. Interestingly, the authors find that expression of TET enzymes responsible for active DNA demethylation mimic TDG expression pattern in hPSCs and NPCs. Taking this into account together with the fact that cellular proliferation diminishes following birth in neural tissues, the authors sought to examine whether this pattern of TDG expression is linked to the cell cycle progression. To this end, the authors found that TDG levels increase during G0/G1 and decrease following entry to $S$ and G2/M phases of the cell cycle. Next, the authors enquired whether the decrease in the differentiation potential of NPCs following TDG KD is due to prolonged proliferative status and show 34 cell cycle related genes amongst the genes differentially expressed upon the TDG knockdown. Finally, using a cell cycle reporter, FUCCI, the authors attempt to link the dynamics of TDG levels during cell cycle with active demethylation of the hPSC genome. Although, the authors show that TDG levels increase in G0/G1 cells and that $5 f C$ and $5 \mathrm{caC}$ begin to accumulate in $\mathrm{S}$ phase, given the absence of what happens to the levels of $5 \mathrm{fC}$ and $5 \mathrm{caC}$ during cell cycle following TDG KD, it is not possible to conclude if TDG impacts the cell 
cycle dynamics of these modifications from the presented results.

Overall, I think that this manuscript presents some novel and interesting data and the authors have a potential to develop this story much further. At the same time there is a number of issues with the current paper that should be fixed before it can be indexed, in my opinion.

In addition to the discrepancies mentioned above that need to be, at least explained in the text, there are following points that would be necessary to address:

1. The authors do not show how their findings on the involvement of TDG in cell cycle regulation impact differentiation of NPCs to either neurons or glia (This can be done by performing MAB-seq on the genes directly involved in neuronal/glial differentiation). It is difficult to understand why TDG depleted NPC have the same ratio of neuron to glial differentiation as the wild type ones (Figure 2E). This is especially strange since it is now well established that affecting the methylation status of differentiating NPCs either directly through modulation of DNMT proteins or by modulating the active DNA demethylation pathway via TDG/TETs, impacts the neuronal to glial differentiation lineage switch.

2. It would make sense to confirm at least the most important findings using an independent siRNA. Moreover, there is no catalogue number for the siRNA used in the manuscript.

3. The effects of TDG depletion on the cell cycle regulation shown in Figure 5 are rather mild. I understand that this can be explained by transient nature of the siRNA mediated depletion but the conclusion that "Taken together, it seems clear that TDG plays a role in human pluripotent stem cell cycle regulation" is an overstatement from my point of view.

4. It is unclear from the Methods section what type of microscopy (conventional or confocal) was used for the cell imaging.

5. Multiple images of the cell nuclei should be shown in Figure 6 for each condition.

6. The nuclei are incorrectly called "nucleotides" in the Figure 6 legend.

7. Both the introduction and discussion are rather short and extremely superficial. Some of the references are cited incorrectly or in improper place. Furthermore, there is a large number of factual sentences in these sections that are lacking any references. Taking this into account, both Introduction and Discussion should be completely rewritten.

Is the work clearly and accurately presented and does it cite the current literature? Partly

Is the study design appropriate and is the work technically sound? Partly

Are sufficient details of methods and analysis provided to allow replication by others? Partly

If applicable, is the statistical analysis and its interpretation appropriate? 
Yes

Are all the source data underlying the results available to ensure full reproducibility? Partly

Are the conclusions drawn adequately supported by the results?

Partly

Competing Interests: No competing interests were disclosed.

Reviewer Expertise: Epigenetics, DNA methylation and demethylation

We confirm that we have read this submission and believe that we have an appropriate level of expertise to confirm that it is of an acceptable scientific standard, however we have significant reservations, as outlined above.

The benefits of publishing with F1000Research:

- Your article is published within days, with no editorial bias

- You can publish traditional articles, null/negative results, case reports, data notes and more

- The peer review process is transparent and collaborative

- Your article is indexed in PubMed after passing peer review

- Dedicated customer support at every stage

For pre-submission enquiries, contact research@f1000.com 